\title{
A STUDY ON NOISE LEVELS OF MACHINERY USED IN LUMBER INDUSTRY ENTERPRISES
}

\author{
Muhammed Said Fidan \\ Bursa Technical University \\ TuRKeY \\ Sekip Sadiye Yasar, Osman Komut, Mehmet Yasar \\ Gumushane University \\ TURKEY \\ (Received Decem2020)
}

\begin{abstract}
The aim of this study is to help to create a healthier environment by measuring the noise levels in the furniture and lumber sectors of forest products industry. In this study, noise measurement for approximately $3 \mathrm{~min}$ has been conducted in 4 measurement spots in the side of the machinery, in the factory entrance and in full and empty state for each machinery; from 3 different chosen spots in enterprises producing lumber. Measurements have been recorded as 720, from each machine as 36 measurements, with the condition to be recorded every $5 \mathrm{sec}$ for $3 \mathrm{~min}$. For this purpose, noise measurements have been carried out in 17 workplaces producing lumber and results have been compared statistically. As a result of the obtained findings, it is understood that the noise levels of thickness machinery don't exceed the value for the upper limit stated in the regulations. However, vertical wood band sawmill and band saw machines have been observed to go over this limit. Besides, some factors of planning and multi slitting machine don't exceed this limit, some of them exceed. As a result, it has been conducted that when noise levels of machinery used in the lumber industry enterprises exceed the upper limit stated in the regulations, they can pose a serious threat to human health.
\end{abstract}

KEYWORDS: Lumber, noise, machinery, work environment, forest products industry.

\section{INTRODUCTION}

Mechanical vibrations caused by a pressure change in unpleasant and unwanted gas, liquid and solids are called noise. The sound is the changes occurred in air pressure which reaches in waves to sensorial organs. The intensity and frequency are expressions for characteristics of a vibration (Akan 2002). An oscillation, expressed as the number of cycles, determines the low 
pitch (low frequency) or the high pitch (high frequency) of the sound with respect to noise. Hertz indicated with " $\mathrm{Hz}$ " symbol is the frequency unit. A young and healthy person can hear the sounds between $20000 \mathrm{~Hz}$ and $20 \mathrm{~Hz}$ (Passchier-Vermeer and Passchier 2000, Muzet 2007). Noise is called as sounds which people dislike and leaves a negative impact on them. Especially our large cities have a noise level that is above measurements determined by the World Health Organization (WHO). Noise, which is generally defined as irritating and unwanted noise, affect human health and body health adversely (Krilek et al. 2016). The noise concept in the industry is the sound that leaves psychological and physiological effects on employees in workplaces and affects the work efficiency, perception and auditory health adversely (Güvercin and Aybek 2003, Durcan and Burdurlu 2018). It is known that the noise level in the woodworking enterprises is high (Lučić et al. 2007, Mandic et al. 2015). For this reason, it is recommended to use ear protectors for those working in such enterprises (Kopecký and Rousek 2012). It is deducted from the studies that the noise has effects varying between individuals and its effects on human health can be listed as following (Güner 2000): (1) Noise has negative effects on people such as loss of concentration, irritability, insomnia and uneasiness. (2) Noise reduces work efficiency along with hindering reasoning. Studies on vocabulary learning and memory are affected by noise. Especially learning experiences in schools are seen to be affected adversely. Its effect of reducing the effectiveness of learning is observed in schools which are close to the noisy areas. Noise; is also important in terms of school health for reasons such as reducing reading, understanding and the level of learning. (3) It can cause problems, increase in depressions and rapid irritation and anger, and may cause problems and depressions and character changes in people who have a tendency towards this direction. (4) Sudden noise can cause adrenal discharges in people, in parallel with this, increase in heart rate and respiratory rate, as well as a rise in blood pressure, disturbed sleep patterns, and attention deficit. The heart rate increasing with sudden noise also causes pupil constriction. The impacts of different noise ranges on humans are described as (Stansfeld and Matheson 2003, Yost 2007, Kasprzak 2014, Erol and Su 2015) 0-35 dB: Non-destructive noise, 36-65 dB: Irritating noise that can disturb sleep and rest, 66-85 dB: Irritating, mentally detrimental noise causing hearing problems, 86-115 dB: Noise damaging mentally and physically, causing psychosomatic diseases, 116-130 dB: Hazardous noise, deafness and suchlike cases, 131-150 dB: Highly hazardous noise cannot be heard without a protective tool. Noise damaging instantly.

It is known that the noise, of which impacts on human health differs among the people, bothers the employees differently with a severity of over $60 \mathrm{~dB}(\mathrm{~A})$ and spreading through the workplace. A rise in sound intensity increases the adverse impacts on the employee health. The reason why enterprises do not pay much attention to the noise issue is that expression of emerged harmful effect takes a long time. This explains why noise originated occupational diseases are most encountered in our national industry. Hearing loss formed in people who are exposed to severe noise above $90 \mathrm{~dB}$ (A) for long periods of time, can occur temporarily or permanently. Temporary hearing loss, arising from being present in a noisy environment for a certain period of time disappears after resting for a given period. However, this duration which should be passed far away from this environment is rather long (Güner 2000). For instance; for a person who is exposed to the noise above $90 \mathrm{~dB}$ (A) for $100 \mathrm{~min}$, that person should stand back of this noisy environment for 1000 minutes to restore this hearing loss. The required time for recovery from this temporary hearing loss is 10 times of noise exposure time. The rise in hearing losses also depends on the increase in noise level. This causes an increase in the time required for recovery (Demir 2012). 
It has been reported that the noise and dust produced by many machines and systems used in the forest products industry is threatening human health (Ratnasingam and Ioras 2010, Hlásková et al. 2015, Robinson et al. 2015, Durcan and Burdurlu 2018). Machinery and cutter types used in wood-processing industries are among the most important factors that increase the noise level (Kvietková et al. 2015). The noise level in the workplace environment is not only directly caused by hearing loss, but also as an important cause of work accidents (Cooper 2000, Clarke 2006, Das et al. 2008, Ratnasingam et al. 2016).

\section{MATERIAL AND METHODS}

In this study, enterprises producing timber in Gümüşhane province at the Eastern Black Sea Region of Turkey has been monitored. In this research, 17 enterprises in lumber sector manufacturing in the forest products industry were studied. The necessary interviews were carried out with enterprises manufacturing limber and furniture in Gümüşhane province; before analyses, required permits were obtained for the determination of noise, measurements were conducted for approximately 3 min from 3 different selected points; machines running in idle and loaded state for each machinery, and in the 4 measuring locations at the factory entrance and near the machine. Measurements were recorded as 36 from each machinery, with the condition to be recorded every $5 \mathrm{sec}$ of $3 \mathrm{~min}$ (Tab. 1). Noise level measurements were made according to PN-EN ISO 9612 (2011) standards (Bilski 2017, Dudarewicz et al. 2018, Pleban 2019).

In this study, the noise levels of the band saw, vertical wood band sawmill machine, thickness machine, planing machine and multi drilling machines, which are available in furniture and timber manufacturing enterprises in Gümüşhane province, were measured.

Tab. 1: Number of noise measurements made by companies engaged in small scale forest products production.

\begin{tabular}{|l|c|c|c|c|c|}
\hline & $\begin{array}{c}\text { Machine is running } \\
\text { in empty condition }\end{array}$ & $\begin{array}{c}\text { Machine is running } \\
\text { in full condition }\end{array}$ & $\begin{array}{c}\text { Introduction of } \\
\text { the business }\end{array}$ & $\begin{array}{c}\text { Next to the } \\
\text { machine }\end{array}$ & $\begin{array}{c}\text { Total number of } \\
\text { measurements }\end{array}$ \\
\hline Band saw machines & 36 & 36 & 36 & 36 & 144 \\
\hline Table saw machines & 36 & 36 & 36 & 36 & 144 \\
\hline Wood thickness machines & 36 & 36 & 36 & 36 & 144 \\
\hline Wood planer machines & 36 & 36 & 36 & 36 & 144 \\
\hline Multi rip saw machines & 36 & 36 & 36 & 36 & 144 \\
\hline Total & \multicolumn{5}{|l|}{} \\
\hline
\end{tabular}

Measurements were carried out in such a manner that there aren't reflections from the employees' location. Other machines were assumed not to operate in the measurements. The constant noise limit value was determined as $85 \mathrm{~dB}(\mathrm{~A})$ by the international labour organization (ILO) and as in the study. In the measurements of machinery and other equipment, measurement position was one meter away from machinery and other equipment and at the hearing level of the employee (Çakır 2010). TESTO 815 device has been used to measure the noise level in the enterprises manufacturing furniture and timber.

The batteries of the noise measuring device have been checked beforehand. Before and after the measurement, the device was calibrated to determine the atmospheric properties (ambient temperature and relative humidity) of the environment where measurements take place. Noise level measurement has been conducted by choosing correct settings according to properties of the device to be used and type of noise to be measured. 
The obtained results of the questionnaire forms were entered into Excel, Word program and then coded for evaluation in SPSS package program and a database was created in the computer environment. For each machine separately, one way variance analysis (One Way Anova) was applied to the created database to determine whether or not there was a significant difference between noise levels on the basis of variables of operation input, machine side, loaded and idle running machine. As a result of this analysis, homogeneity test (Post $\mathrm{Hoc}$ ) has been conducted to determine the statistical analysis method which will be used to determinate among which variables of this contrast occurred. For cases where homogeneity of variance result was $p>0.05$, variances distributed in a uniform and for cases where it was $\mathrm{P}<0.05$, the distribution of variances was not in a uniform. In the conducted homogeneity test, the statistical significance level was measured as $\mathrm{p}<0.05$ and Dunnett T3 test was used for the tests under the title of Equal Variances Not Assumed. On the other hand, descriptive statistics like frequency, \%, mean, standard deviation and standard error were used in the data evaluation.

\section{RESULTS AND DISCUSSION}

The results of the homogeneity test of the obtained findings were determined as a result of the measurements conducted for the band saws, vertical wood band sawmill, thickness, planing and multi-slitting machineries utilized in the enterprises (Tab. 2).

Tab. 2: Homogeneity test results for machines used in enterprises.

\begin{tabular}{|l|c|c|c|c|}
\hline Name of machines & Stt. & df1 & df2 & Sig. \\
\hline Table saw machines & 856.832 & 3 & 3164 & 0.000 \\
\hline Band saw machines & 42.842 & 3 & 2444 & 0.000 \\
\hline Wood thickness machines & 165.491 & 3 & 2444 & 0.000 \\
\hline Wood planer machines & 248.064 & 3 & 2444 & 0.000 \\
\hline Multi rip saw machines & 291.662 & 3 & 2444 & 0.000 \\
\hline
\end{tabular}

It has been determined that there are statistically significant differences with a significance level of $1 \%$ between the measurement location and machine status factors in terms of noise levels in band saws, vertical wood band sawmill saws, thickness, planing and multi-slitting machines used in enterprises (Tab. 3).

Tab. 3: Variance analysis results of noise levels of machines used in enterprises.

\begin{tabular}{|l|c|c|c|c|c|}
\hline Variation source & $\begin{array}{c}\text { Degrees of } \\
\text { freedom }\end{array}$ & Sum of squares & Mean squares & F- value & Sig. \\
\hline \multicolumn{7}{|c|}{ Table saw machines } \\
\hline Between Groups & 1234.310 & 3 & 411.437 & $533.559^{*}$ & 0.000 \\
\hline Within Groups & 2439.815 & 3164 & 0.771 & & \\
\hline Total & 3674.124 & 3167 & & & \\
\hline \multicolumn{7}{|c|}{ Band saw machines } \\
\hline Between Groups & 48.850 & 3 & 16.283 & $238.695^{*}$ & 0.000 \\
\hline Within Groups & 166.725 & 2444 & 0.068 & & \\
\hline Total & 215.575 & 2447 & & & \\
\hline
\end{tabular}


Vol. 65 (5): 2020

\begin{tabular}{|l|c|c|c|c|c|}
\hline \multicolumn{7}{|c|}{ Wood thickness machines } \\
\hline Between Groups & 1675.765 & 3 & 558.588 & $276.072^{*}$ & 0.000 \\
\hline Within Groups & 4945.043 & 2444 & 2.023 & & \\
\hline Total & 6620.808 & 2447 & & & \\
\hline \multicolumn{7}{|c|}{ Wood planer machines } \\
\hline Between Groups & 6690.819 & 3 & 2230.273 & $6092.754^{*}$ & 0.000 \\
\hline Within Groups & 894.634 & 2444 & 0.366 & & \\
\hline Total & 7585.453 & 2447 & & & \\
\hline \multicolumn{7}{|c|}{ Multi rip saw machines } & \\
\hline Between Groups & 28786.236 & 3 & 9595.412 & $1822.66^{*}$ & 0.000 \\
\hline Within Groups & 12866.460 & 2444 & 5.265 & & \\
\hline Total & 41652.696 & 2447 & & & \\
\hline
\end{tabular}

As shown in Tab. 4, the distribution and statistical analysis of the band saws, vertical wood band sawmill, thickness, planing and multi-slitting machines used in the enterprises concerning their noise levels have been given according to the measurement location and machine status in the scope of the study. The highest noise level for the band saw machinery was determined as $87.31 \mathrm{~dB}$ in the machine side measurement location and loaded machine condition. On the other hand, the lowest value was determined as $85.80 \mathrm{~dB}$ in the factory entrance measurement location and the idle machine status (Tab. 4). The highest noise level in the vertical wood band sawmill machine was $87.55 \mathrm{~dB}$ in the workshop entrance and loaded machine status. But, the lowest level was $87.22 \mathrm{~dB}$ in the side of machine and idle machine status (Tab. 4). According to this result, the noise levels of the band saw machine and vertical wood band sawmill machine have been found to go over the upper limit of $85 \mathrm{~dB}$ (A) specified in the regulations. The highest noise level in the thickness machine was found out as $84.44 \mathrm{~dB}$ in the machine side measurement location and the loaded machine. On the other hand, the lowest level was $82.23 \mathrm{~dB}$ in the side of machine measurement location and idle machine. And so, the noise levels of the thickness machine were determined not to exceed the upper limit of $85 \mathrm{~dB}$ (A) specified in the regulations (Tab. 4). The highest noise level in the planing machine in the side of machine and loaded machine status was identified as $86.43 \mathrm{~dB}$. Furtmermore, the lowest level was $82.43 \mathrm{~dB}$ in the workshop entrance measurement location and idle machine status. In this case, it was observed that the noise levels of the planing machine for the machine side measurement location and loaded machine status exceeded the upper limit value of $85 \mathrm{~dB}$ (A) stated in the regulations, this limit wasn't exceeded in other factors (Tab. 4). The highest noise level in the multi-slitting machine was $85.93 \mathrm{~dB}$ in the machine side measurement location and the loaded machine status. On the other hand, the lowest was $76.30 \mathrm{~dB}$ in the workshop entrance measurement location and idle machine status. Then, the noise level of the multi-slitting machine for the machine side measurement location and loaded status was discovered to go over the upper limit of $85 \mathrm{~dB}$ (A) stated in the regulations, the other factors did not exceed this limit (Tab. 4). 
Tab. 4: Average values of noise levels of machines used in enterprises.

\begin{tabular}{|c|c|c|c|c|c|c|c|c|c|c|}
\hline & $\begin{array}{c}\text { Measurement } \\
\text { location }\end{array}$ & $\begin{array}{c}\text { Machine } \\
\text { status }\end{array}$ & $\begin{array}{l}\text { Min } \\
(\mathrm{dB})\end{array}$ & $\begin{array}{r}\text { Max } \\
(\mathrm{dB})\end{array}$ & $\begin{array}{c}\text { Average } \\
\text { (dB) }\end{array}$ & $\begin{array}{l}\text { Standart } \\
\text { deviation }\end{array}$ & Std. error & $\begin{array}{l}\text { Average- } \\
\text { Boundary } \\
\text { value } \\
\text { difference }\end{array}$ & $\begin{array}{l}\text { Momentary } \\
\text { Max.-Boundary } \\
\text { value difference }\end{array}$ & $\begin{array}{c}\text { Idle / Load } \\
\text { change rate ( } \% \\
\text { by average) }\end{array}$ \\
\hline \multirow{4}{*}{$\begin{array}{l}\text { Table saw } \\
\text { machines }\end{array}$} & \multirow{2}{*}{$\begin{array}{l}\text { Workshop } \\
\text { entrance }\end{array}$} & Idled & 83.30 & 87.00 & 85.80 & 0.80542 & 0.02862 & 0.80 & 2.00 & \multirow{2}{*}{1.7} \\
\hline & & Load & 84.90 & 88.60 & 87.24 & 1.31273 & 0.04665 & 2.24 & 3.60 & \\
\hline & \multirow{2}{*}{$\begin{array}{l}\text { Next to the } \\
\text { machine }\end{array}$} & Idled & 84.80 & 88.10 & 87.23 & 0.75383 & 0.02679 & 2.23 & 3.10 & \multirow{2}{*}{0.1} \\
\hline & & Load & 86.10 & 88.10 & 87.31 & 0.37981 & 0.01350 & 2.31 & 3.10 & \\
\hline \multirow{4}{*}{$\begin{array}{l}\text { Band saw } \\
\text { machines }\end{array}$} & \multirow{2}{*}{$\begin{array}{l}\text { Workshop } \\
\text { entrance }\end{array}$} & Idled & 86.60 & 87.80 & 87.25 & 0.27128 & 0.01097 & 2.25 & 2.80 & \multirow{2}{*}{0.3} \\
\hline & & Load & 87.10 & 87.90 & 87.55 & 0.22028 & 0.00890 & 2.55 & 2.90 & \\
\hline & \multirow{2}{*}{$\begin{array}{c}\text { Next to the } \\
\text { machine }\end{array}$} & Idled & 86.60 & 87.60 & 87.22 & 0.22545 & 0.00911 & 2.22 & 2.60 & \multirow{2}{*}{0.3} \\
\hline & & Load & 86.80 & 88.10 & 87.48 & 0.31611 & 0.01278 & 2.48 & 3.10 & \\
\hline \multirow{4}{*}{$\begin{array}{l}\text { Wood } \\
\text { thickness } \\
\text { maachines }\end{array}$} & \multirow{2}{*}{$\begin{array}{c}\text { Workshop } \\
\text { entrance }\end{array}$} & Idled & 78.00 & 86.50 & 82.93 & 1.62782 & 0.06580 & -2.07 & 1.5 & \multirow{2}{*}{-0.3} \\
\hline & & Load & 79.20 & 85.90 & 82.71 & 1.37010 & 0.05538 & -2.29 & 0.9 & \\
\hline & \multirow{2}{*}{$\begin{array}{l}\text { Next to the } \\
\text { machine }\end{array}$} & Idled & 81.30 & 83.90 & 82.23 & 0.61964 & 0.02505 & -2.77 & -1.1 & \multirow{2}{*}{2.7} \\
\hline & & Load & 81.10 & 87.60 & 84.44 & 1.78394 & 0.07211 & -0.56 & 2.6 & \\
\hline \multirow{4}{*}{$\begin{array}{c}\text { Wood } \\
\text { planer } \\
\text { machines }\end{array}$} & \multirow{2}{*}{$\begin{array}{c}\text { Workshop } \\
\text { entrance }\end{array}$} & Idled & 81.40 & 83.80 & 82.43 & 0.38768 & 0.01567 & -2.57 & -1.2 & \multirow{2}{*}{4.4} \\
\hline & & Load & 85.20 & 87.20 & 86.02 & 0.51602 & 0.02086 & 1.02 & 2.2 & \\
\hline & \multirow{2}{*}{$\begin{array}{l}\text { Next to the } \\
\text { machine }\end{array}$} & Idled & 82.60 & 84.20 & 83.67 & 0.26958 & 0.01090 & -1.33 & -0.8 & \multirow{2}{*}{3.3} \\
\hline & & Load & 84.10 & 88.30 & 86.43 & 0.9874 & 0.03991 & 1.43 & 3.3 & \\
\hline \multirow{4}{*}{$\begin{array}{c}\text { Multi } \\
\text { rip saw } \\
\text { machines }\end{array}$} & \multirow{2}{*}{$\begin{array}{c}\text { Workshop } \\
\text { entrance }\end{array}$} & Idled & 71.10 & 79.50 & 76.30 & 2.86981 & 0.11601 & -8.70 & -5.50 & \multirow{2}{*}{7.1} \\
\hline & & Load & 75.50 & 87.30 & 81.69 & 2.92006 & 0.11804 & -3.31 & 2.30 & \\
\hline & \multirow{2}{*}{$\begin{array}{l}\text { Next to the } \\
\text { machine }\end{array}$} & Idled & 77.40 & 83.00 & 80.72 & 1.27753 & 0.05164 & -4.28 & -2.00 & \multirow{2}{*}{6.5} \\
\hline & & Load & 81.40 & 88.10 & 85.93 & 1.63200 & 0.06597 & 0.93 & 3.10 & \\
\hline
\end{tabular}

Accordingly, since the significance level was calculated below $0.05(\mathrm{p}<0.05)$, it was detected that the data were not distributed homogeneously. Hence, (Post Hoc) Dunnett T3 test was carried out to determine between which groups the statistically significant difference in noise level measurement occurred and the obtained results were detected as in Tab. 5. In Tab. 5, for the Post Hoc analysis conducted by using the Dunnett T3 test, there were no statistically significant differences between the loaded status of the workshop entrance and the idle status in the side of the machine; idle state in the side of the machine and loaded status in the workshop entrance; the loaded and idle status in the side of the machine; statistically significant differences were observed in other comparative cases. Furthermore, statistically significant differences were found to be formed at all comparative cases of vertical wood band sawmill, planing and multi-slitting machinery measurements. On the other hand, there were no statistically significant differences in terms of the noise level between in idle state and workshop entrance; in loaded state and workshop entrance; in idle state and workplace entrance (Tab. 5). 
Vol. 65 (5): 2020

Tab. 5: Groups formed according to Dunnett T3 test for noise levels of machines used in enterprises.

\begin{tabular}{|c|c|c|c|c|c|c|c|c|c|}
\hline & $\begin{array}{l}\text { Measurement location - } \\
\text { Machine status }\end{array}$ & & $\begin{array}{c}\text { Mean } \\
\text { difference } \\
(\mathrm{I}-\mathrm{J})\end{array}$ & $\begin{array}{l}\text { Standard } \\
\text { error }\end{array}$ & Sig. & & $\begin{array}{c}\text { Mean } \\
\text { difference } \\
(\mathrm{I}-\mathrm{J})\end{array}$ & $\begin{array}{c}\text { Standard } \\
\text { error }\end{array}$ & Sig. \\
\hline \multirow{3}{*}{$\begin{array}{l}\text { Workshop } \\
\text { entrance- Idled }\end{array}$} & Workshop entrance- Load & \multirow{12}{*}{ 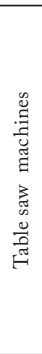 } & $-1.34369^{*}$ & 0.05473 & 0.000 & \multirow{12}{*}{ 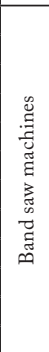 } & $-0.29216^{*}$ & 0.01413 & 0.000 \\
\hline & Next to the machine- Idled & & $-1.45530^{*}$ & 0.03920 & 0.000 & & $0.04003^{*}$ & 0.01426 & 0.030 \\
\hline & Next to the machine- Load & & $-1.50631^{*}$ & 0.03164 & 0.000 & & $-0.22092^{*}$ & 0.01684 & 0.000 \\
\hline \multirow{3}{*}{$\begin{array}{l}\text { Workshop } \\
\text { entrance- Load }\end{array}$} & Workshop entrance- Idled & & $1.34369^{*}$ & 0.05473 & 0.000 & & $0.29216^{*}$ & 0.01413 & 0.000 \\
\hline & Next to the machine- Idled & & -0.11162 & 0.05379 & 0.208 & & $0.33219^{*}$ & 0.01274 & 0.000 \\
\hline & Next to the machine- Load & & $-0.16263^{*}$ & 0.04856 & 0.005 & & $0.07124^{*}$ & 0.01557 & 0.000 \\
\hline \multirow{3}{*}{$\begin{array}{l}\text { Next to the } \\
\text { machine- Idled }\end{array}$} & Workshop entrance- Idled & & $1.45530^{*}$ & 0.03920 & 0.000 & & $-0.04003^{*}$ & 0.01426 & 0.030 \\
\hline & Workshop entrance- Load & & 0.11162 & 0.05379 & 0.208 & & $-0.33219^{*}$ & 0.01274 & 0.000 \\
\hline & Next to the machine- Load & & -0.05101 & 0.02999 & 0.429 & & $-0.26095^{*}$ & 0.01569 & 0.000 \\
\hline \multirow{3}{*}{$\begin{array}{l}\text { Next to the } \\
\text { Machine- Load }\end{array}$} & Workshop entrance- Idled & & $1.50631^{*}$ & 0.03164 & 0.000 & & $0.22092^{*}$ & 0.01684 & 0.000 \\
\hline & Workshop e & & $0.16263^{*}$ & 0.04856 & 0.005 & & $-0.07124^{*}$ & & 0.000 \\
\hline & Next & & 0.05101 & 0.02999 & 0.429 & & $0.26095^{*}$ & & 0.000 \\
\hline \multirow{3}{*}{$\begin{array}{l}\text { Workshop } \\
\text { entrance- Idled }\end{array}$} & Load & \multirow{12}{*}{ 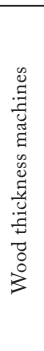 } & 0.21993 & 0.08601 & 0.062 & \multirow{12}{*}{ 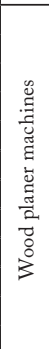 } & $-3.58824^{*}$ & 09 & 0.000 \\
\hline & e- Idled & & $0.70114^{*}$ & 0.07041 & 0.000 & & $-1.23546^{*}$ & 0.01909 & 0.000 \\
\hline & Next to the & & $-1.51176^{*}$ & 0.09762 & 0.000 & & $-3.99869^{*}$ & 0.04288 & 0.000 \\
\hline \multirow{3}{*}{$\begin{array}{l}\text { Workshop } \\
\text { entrance- Load }\end{array}$} & Workshop entrance- Idled & & -0.2199 & 0.08601 & 0.062 & & $3.58824^{*}$ & 0.02609 & 0.000 \\
\hline & \begin{tabular}{|l|} 
Next to the machine- Idled \\
\end{tabular} & & $0.48121^{*}$ & 0.06078 & 0.000 & & $2.35278^{*}$ & 0.02353 & 0.000 \\
\hline & Next to the machine- Load & & $-1.73170^{*}$ & 0.09092 & 0.000 & & $-0.41046^{*}$ & 0.04504 & 0.000 \\
\hline \multirow{3}{*}{$\begin{array}{l}\text { Next to the } \\
\text { machine- Idled }\end{array}$} & Workshop entrance- Idled & & $-0.70114^{*}$ & 0.07041 & 0.000 & & $1.23546^{*}$ & 0.01909 & 0.000 \\
\hline & \begin{tabular}{|l} 
Workshop entrance- Load \\
\end{tabular} & & $-0.48121^{*}$ & 0.06078 & 0.000 & & $-2.35278^{*}$ & 0.02353 & 0.000 \\
\hline & Next to the machine- Load & & $-2.21291^{*}$ & 0.07634 & 0.000 & & $-2.76324^{*}$ & 0.04137 & 0.000 \\
\hline \multirow{3}{*}{$\begin{array}{l}\text { Next to the } \\
\text { machine- Load }\end{array}$} & Workshop entrance- Idled & & $1.51176^{*}$ & 0.09762 & 0.000 & & $3.99869^{*}$ & 0.04288 & 0.000 \\
\hline & Workshop entrance- Load & & $1.73170^{*}$ & 0.09092 & 0.000 & & $0.41046^{*}$ & 0.04504 & 0.000 \\
\hline & Next to the machine- Idled & & $2.21291^{*}$ & 0.07634 & 0.000 & & $2.76324^{*}$ & 0.04137 & 0.000 \\
\hline \multirow{3}{*}{$\begin{array}{l}\text { Workshop } \\
\text { entrance- Idled }\end{array}$} & Workshop entrance- Load & \multirow{12}{*}{ 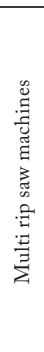 } & $-5.34559^{*}$ & 0.1655 & 0.000 & & & & \\
\hline & Next to the machine- Idled & & $-4.41699^{*}$ & 0.12698 & 0.000 & & & & \\
\hline & \begin{tabular}{|l|} 
Next to the machine- Load \\
\end{tabular} & & $-9.65425^{*}$ & 0.13345 & 0.000 & & & & \\
\hline \multirow{3}{*}{$\begin{array}{l}\text { Workshop } \\
\text { entrance- Load }\end{array}$} & Workshop entrance- Idled & & $5.34559^{*}$ & 0.1655 & 0.000 & & & & \\
\hline & Next to the machine- Idled & & $0.92859^{*}$ & 0.12884 & 0.000 & & & & \\
\hline & Next to the machine- Load & & $-4.30866^{*}$ & 0.13522 & 0.000 & & & & \\
\hline \multirow{3}{*}{$\begin{array}{l}\text { Next to the } \\
\text { machine- Idled }\end{array}$} & Workshop entrance- Idled & & $4.41699^{*}$ & 0.12698 & 0.000 & & & & \\
\hline & Workshop entrance- Load & & $-0.92859^{*}$ & 0.12884 & 0.000 & & & & \\
\hline & Next to the machine- Load & & $-5.23725^{*}$ & 0.08378 & 0.000 & & & & \\
\hline \multirow{3}{*}{$\begin{array}{l}\text { Next to the } \\
\text { machine- Load }\end{array}$} & Workshop entrance- Idled & & $9.65425^{*}$ & 0.13345 & 0.000 & & & & \\
\hline & Workshop entrance- Load & & $4.30866^{*}$ & 0.13522 & 0.000 & & & & \\
\hline & Next to the machine- Idled & & $5.23725^{*}$ & 0.08378 & 0.000 & & & & \\
\hline
\end{tabular}

It was observed that the noise levels of the vertical wood band sawmill machines operating in the enterprises came out in values rather different from each other according to cases of idle and loaded states at the workshop entrance and side of the machine (Fig. 1). On the other hand, it turned out quite different from each other at workshop entrance and the machine side (Fig. 2). As seen in Fig. 3, it was detected that noise levels of the thickness machine operating in the enterprises came out close to each other at the workshop entrance and the machine side. It was found out that the noise levels of the planing machines operating in the enterprises are different were rather different from each other according to cases of idle \& loaded status and workshop entrance $\&$ the machine sides (Fig. 4). As it can be seen in Fig. 5, it has been detected that the noise levels of the multi-slitting machines operating in the enterprises are in quite different values from each other with respect to cases of idle \& loaded status and workshop entrance $\&$ the machine sides. 


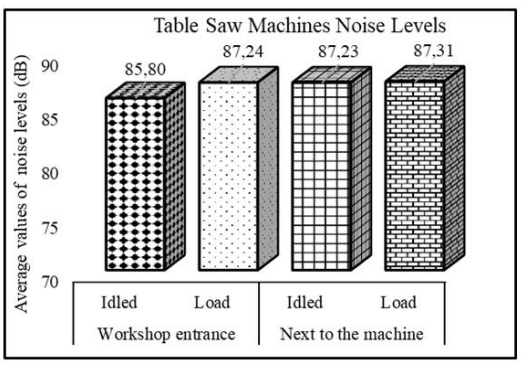

Fig. 1: Average values of noise levels of table saw machines.

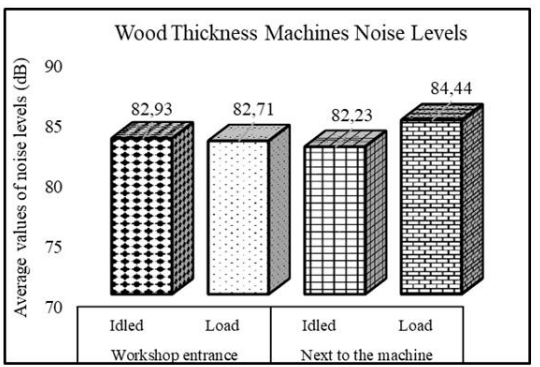

Fig. 3: Average values of noise levels of wood thickness machines.

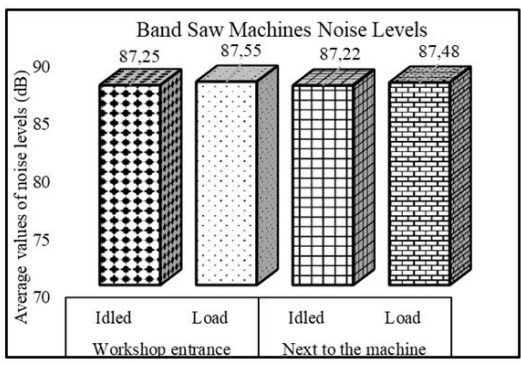

Fig. 2: Average values of noise levels of band saw machine.

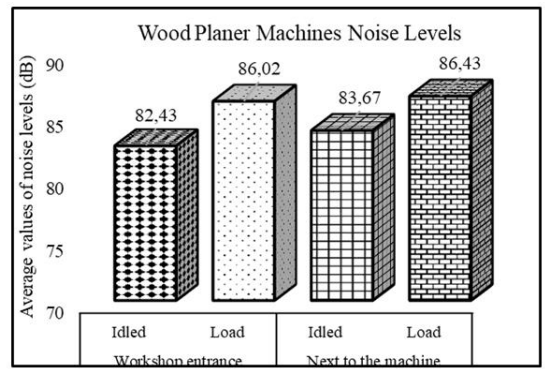

Fig. 4: Average values of noise levels of wood planer machines.

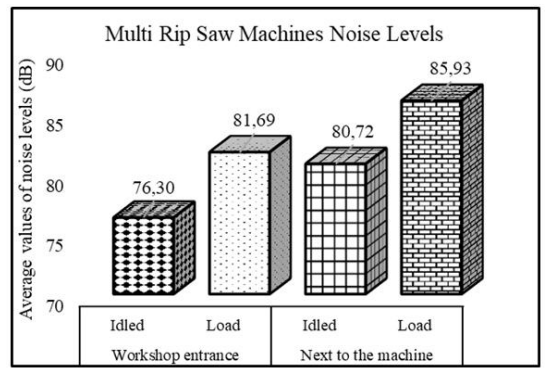

Fig. 5: Average values of noise levels of multi rip saw machines.

Many scientific studies have been conducted to report that the noise generated by the machines used in the timber industry within the scope of different factors such as wood type processed, number of blades, depth of cut and width has reached a level that may adversely affect employee health (Ntalos and Papadopoulas 2005, Ratnasingam et al. 2010, Durcan and Burdurlu 2018). The findings obtained in the study are similar to the results of these studies. On the other hand, it has been reported that high noise levels may cause psychological disorders and motivation losses in addition to physiological disorders in employees (Muzet 2007, Leventhall 2009). 


\section{CONCLUSIONS}

The highest noise levels of machineries utilized in enterprises in the woodworking and furniture industries were observed as following; for thickness machine in loaded machine and the machine side position; for band saw machineries in the side of machine and the loaded machine status; for the planing machines in loaded machine status and the machine side; for vertical wood band sawmill in the workshop entrance and the loaded machine status; and for the multi slitting machines in loaded status and machine side status. The lowest noise levels of machineries used in enterprises in woodworking and furniture industries were found out as following; for thickness machine in machine side measurement location and idle machine status; for band saw machineries in workshop entrance and idle status; for planing machineries in the workshop entrance and idle status; for vertical wood band sawmill machineries in idle status and side of the machine; and for multi slitting machineries in workshop entrance and idle status.

As a result of these; the noise level of the thickness machine does not exceed $85 \mathrm{~dB}(\mathrm{~A})$, which is the upper limit value stated in the regulations; the noise levels of the band saw machine exceeds the upper limit of $85 \mathrm{~dB}(\mathrm{~A})$ specified in the regulations; the noise level of the planing machine exceeds the upper limit of $85 \mathrm{~dB}$ (A) stated in the regulations for the machine side measurement location and loaded machine status, it doesn't exceed this limit for other factors; the noise levels of the vertical wood band sawmill machinery exceeds the upper limit of $85 \mathrm{~dB}$ (A) specified in the regulations; the noise level of the multi-slitting machinery exceeds the upper limit of $85 \mathrm{~dB}$ (A) stated in the regulations for the machine side measurement location and loaded machine status, and it doesn't exceed this limit for other factors. As a consequence of these; it has been determined that the noise levels of the thickness machine do not exceed the upper limit of $85 \mathrm{~dB}$ (A) specified in the regulations. However, the vertical wood band sawmill machine and band saw machineries have been observed to go over this limit. Besides; some factors of the planing machine and multi-slitting machines don't exceed this limit, and some of them seem to exceed.

In conclusion, it has been deduced that the noise levels of the machineries used in enterprises in the woodworking and furniture industries can pose a serious danger to human health when they exceed this upper limit specified in the regulations.

\section{ACKNOWLEDGEMENTS}

This study was supported as scientific research Project (Project Number: 17.B0116.02.01), Gumushane University, Gumushane 2018 (in Turkish).

\section{REFERENCES}

1. Akan, Z., 2002: Effects of noise pollution on employees in van airport. M.Sc. thesis. Van Yüzüncü Y1l University, 86 pp.

2. Bilski, B., 2017: Exposure to infrasonic noise in agriculture. Annals of Agricultural and Environmental Medicine 24(1): 86-89.

3. Clarke, S., 2006: The relationship between safety climate and safety performance: A metaanalytic review. Journal of Occupational Health Psychology 11(1): 315-327.

4. Cooper, M.D., 2000: Towards a model of safety culture. Safety Science 36(2): 111-136. 
5. Çakır, A., 2010: Determination of noise level in 7 factories working on furniture manufacturing and investigation of hearing loss due to noise. M.Sc. thesis. Gazi University Faculty of Health Sciences, Ankara, 70 pp.

6. Das, A., Pagell, M. Behm, M., Veltri, A., 2008: Toward a theory of the linkages between safety and quality. Journal of Operation Management 26(4): 521-535.

7. Demir, S., 2012: Noise level in furniture production facilities in Kahramanmaraş. M.Sc. thesis. KSÜ Institute of Natural Sciences, 86 pp.

8. Dudarewicz, A., Zaborowski, K., Wolniakowska, A., Pawlaczyk-Luszczynska, M., Sliwinska- Kowalska, M., 2018: Evaluation of on-the-job noise exposure in the case of bartenders. Medycyna Pracy 69(6): 633-641.

9. Durcan, F.M., Burdurlu, E., 2018: Effects of some machining parameters on noise level in planing of some wood materials. BioResources 13(2): 2702-2714.

10. Erol, İ., Su, O., 2015: Noise in a mechanized underground mining plant investigation of levels. Çukurova University Journal of the Faculty of Engineering and Architecture 30(2): 191-200.

11. Güner, Ç., 2010: Effects of noise on health. Journal of Continuing Medical Education 9(7): 251-253.

12. Güvercin, Ö., Aybek, A., 2003: Noise problem in crushing and screening plants. KSU Journal of Science and Engineering 6(2): 101-107.

13. Hlásková, L., Rogoziński, T., Dolny, S., Kopecký, Z., Jediná, M., 2015: Content of respirable and inhalable fractions in dust created at sawing beech wood and its modifications. Drewno 58(194): 135-146.

14. Kasprzak, C. 2014: The infuence of infrasound noise from wind turbines on EEG signal patterns in humans. Acta Physica Polonica A 125(2014): A20-A23.

15. Kopecký, Z., Rousek, M., 2012: Impact of dominant vibrations on noise level of dimension circular sawblades. Wood Research 57(1): 151-160.

16. Krilek, J., Ján Kováč, J., Barcík, Š., Svoreň, J., Štefánek, M., Kuvik, T., 2016: The influence of chosen factors of a circular saw blade on the noise level in the process of cross cutting wood. Wood Research 61(3): 475-486.

17. Kvietková, M., Gaff, M., Gašparík, M., Kminiak, R., Kriš, A., 2015: Effect of number of saw blade teeth on noise level and wear of blade edges during cutting of wood. BioResources 10(1): 1657-1666.

18. Leventhall, G., 2009: Low frequency noise. What we know, what we do not know, and what we would like to know. Journal of Frequency Noise, Vibration and Active Control 28(2): 79-104.

19. Lučić, R.B., Čavlović, A., Dukić, I., 2007: Factors influencing particle size distribution of oak and fir saw dust in circular sawing. Wood Research 52(1): 35-46.

20. Mandic, M., Svrzic, S., Danon, G., 2015: The comparative analysis of two methods for the power consumption measurement in circular saw cutting of laminated particle board. Wood Research 60(1): 125-136.

21. Muzet, A., 2007: Environmental noise, sleep and health. Sleep Medicine Reviews 11: 135-142.

22. Ntalos, G.A., Papadopoulas, A.N., 2005: Noise emission levels in Greek wood and furniture processing industry. Journal of the Institute of Wood Science 175(98): 99-103.

23. Passchier-Vermeer, W., Passchier, W.F., 2000: Noise exposure and public health. Environmental Health Perspectives 108(Suppl 1): 123-131. 
24. Pleban, D., 2019: Admissible values and methods of measurement of noise ultrasonic noise and infrasonic noise at workplaces Poland. In. Proceedings of the $23^{\text {rd }}$ International congress on acoustics. 9-13 September 2019 in Aachen, Germany, Pp 7057-7063.

25. PN EN ISO 9612, 2011: Acoustics-determination of occupational noise exposureengineering method.

26. Ratnasingam, J., Ioras, F., 2010: The safety and health of workers in the Malaysian wooden furniture industry: An assessment of noise and chemical solvents exposure. Journal of Applied Sciences 10(7): 590-594.

27. Ratnasingam, J., Natthondan, V., Ioras, F., McNulty, T., 2010: Dust, noise and chemical solvents exposure of workers in the wooden furniture industry in South East Asia. Journal of Applied Sciences 10: 1413-1420.

28. Ratnasingam, J., Ramasamy, G., Ioras, F., Thanesegaran, G., Mutthiah, N., 2016: Assessment of dust emission and working conditions in the bamboo and wooden furniture industries in Malaysia. BioResources 11(1): 1189-1201.

29. Robinson, T., Whittaker, J., Acharya, A., Singh, D., Smith, M., 2015: Prevalence of noiseinduced hearing loss among woodworkers in Nepal: A pilot study. International Journal of Occupational and Environmental Health 21(1): 14-22.

30. Stansfeld, S.A., Matheson, M.P., 2003: Noise pollution: non-auditory effects on health. British Medical Bulletin 68(1): 243-257.

31. Yost, W.A., 2007: Hearing thresholds, loudness of sound and sound adaptation in, handbook of noise and vibration control. Ed Crocker, M.J., John Wiley\&Sons, New York, Pp 286-292.

\author{
Muhammed Said Fidan* \\ Bursa Technical University \\ FACUlty of Forestry \\ Department of Forest Industry Engineering \\ I63IO BuRsA \\ Turkey \\ *Corresponding author: said.fidan@btu.edu.tr \\ Sekip Sadiye Yasar, Mehmet Yasar \\ Gumushane University \\ Gumushane Vocational High School \\ Department of Desing \\ 29100 Gumushane \\ TurKey \\ Osman Komut \\ Gumushane University \\ Gumushane Vocational High School \\ Department of Forestry and Forest Product \\ 29ioo Gumushane \\ TURKEY
}


